\title{
Proses Pendiagnosaan Penyakit Menggunakan Logika Fuzzy Dengan Metode Mamdani
}

\author{
Darmawati \\ Jurusan Matematika FMIPA Universitas Sulawesi Barat; \\ e-mail: dharmawangs89@gmail.com
}

\begin{abstract}
Abstrak
Logika fuzzy merupakan cabang dari logika klasik. Logika fuzzy lahir setelah logika klasik dianggap terlalu eksak untuk masalah nyata yang terkadang begitu kompleks. Salah satunya adalah proses pendiagnosaan penyakit, yang menjadi hal penting dan mendasar dalam kedokteran. Hal ini disebabkan pengambilan tindakan terapi dan pengobatannya berdasarkan pada hasil diagnosa itu. Dengan bantuan Fuzzy Expert System (FES) pada metode Mamdani, dapat diperoleh hasil perkiraan diagnosa untuk seorang pasien terhadap suatu penyakit dengan memperhatikan gejala penyakit tersebut. Metode Mamdani mempunyai empat tahapan proses yaitu: 1. Pembentukan himpunan fuzzy, 2. Aplikasi fungsi implikasi, 3. Mengkomposisikan aturan, 4. Penegasan (defuzzyfikasi). Hasil penelitian menunjukkan bahwa, perkiraan diagnosa yang diperoleh dengan menggunakan logika fuzzy dengan metode Mamdani memberikan hasil yang masih berada dalam interval diagnosa para dokter yang menangani penyakit-penyakit tersebut.
\end{abstract}

Kata kunci: Logika fuzzy, Metode Mamdani, Fuzzy Expert System (FES), Gejala, Penyakit, Pasien.

\section{PENDAHULUAN}

Pada masa kini logika fuzzy bukanlah suatu hal yang baru dalam disiplin ilmu. Logika fuzzy merupakan cabang dari teori fuzzy yang juga memberikan peran yang besar dalam perkembangan ilmu pengetahuan, terutama dalam konsep logika itu sendiri. Logika fuzzy adalah istilah yang lahir setelah sistem analisis matematika tradisional saat itu dianggap bersifat terlalu eksak sehingga tidak dapat berfungsi dalam banyak masalah dunia nyata yang seringkali amat kompleks dikutip dari Susilo, F (2006). Salah satu bidang yang dinilai amat kompleks adalah proses pendiagnosaan suatu penyakit dalam bidang kedokteran. Hal ini disebabkan oleh ketidakpastian yang seringkali ditemukan pada proses diagnosa penyakit. Proses pendiagnosaan suatu penyakit menjadi hal yang penting dan mendasar dalam kedokteran. Hal ini dikarenakan oleh pengambilan tindakan terapi dan pengobatannya berdasarkan pada hasil diagnosa penyakit itu.

Meskipun pengetahuan medis yang berhubungan dengan hubungan antara gejala dengan penyakit terus menjadi salah satu sumber ketidaktepatan dan ketidakpastian proses diagnosa, pengetahuan yang berhubungan dengan keadaan pasien merupakan sumber ketidakpastian yang lain. Dokter biasanya mengumpulkan pengetahuan tentang pasien dari riwayat sebelumnya. Pengetahuan yang disediakan oleh masing-masing pasien dari riwayat sebelumnya memiliki derajat ketidakpastian yang berbeda dalam Setiadji (2009). 
Salah satu aplikasi logika fuzzy yang digunakan untuk mendiagnosis penyakit adalah sistem pakar dengan inferensi fuzzy atau Fuzzy Expert System (FES), yaitu sistem komputasi lunak yang bekerja atas dasar penalaran fuzzy. FES telah banyak digunakan untuk menyelesaikan berbagai masalah dalam bidang kedokteran. Sistem ini dapat digunakan sebagai langkah pengambilan keputusan untuk mengindikasikan adanya suatu penyakit dalam Saritas dkk ( 2003). Salah satu metode yang dapat digunakan dalam FES adalah metode Mamdani. Data yang diperlukan untuk membangun sistem ini adalah gejala penyakit sebagai variabel input, sedangkan variabel output yang dihasilkan adalah persentase resiko dari penyakit yang akan didiagnosa. Dari variabel input dan output tersebut ditentukan himpunan fuzzy dan fungsi keanggotaannya, kemudian membuat kombinasi dari variabel input untuk mendapatkan aturan-aturan fuzzy (fuzzy rules). Dari aturan yang sudah dibuat, maka inferensi sistem fuzzy dapat dilakukan dengan menentukan aplikasi fungsi implikasi, komposisi aturan dan metode penegasan (defuzzyfikasi). Dari hasil yang diperoleh, didapatkan sebuah kesimpulan diagnosis untuk seorang pasien.

Penelitian ini dibatasi pada penyakit Gagal Ginjal Kronik stadium IV-V. Sedangkan fungsi keanggotaan yang digunakan pada tiap variabel fuzzy ditentukan secara subyektif berdasarkan pandangan para dokter ahli dan literatur yang ada dalam ilmu kedokteran.

\section{METODE PENELITIAN}

Untuk mendapatkan suatu hasil diagnosa untuk seorang pasien, logika fuzzy dengan metode mamdani memerlukan empat tahapan proses setelah pengambilan data. Data yang dipakai dalam penelitian ini merupkan data wawancara dengan Dokter ahli dan pasiennya, yang bertempat di Rumah Sakit Umum Daerah Undata Palu ,Sulawesi Tengah. Data yang diperoleh kemudian ditentukan variabel input dan variabel outputnya beserta fungsi keanggotaannya. Kemudian setelah itu membuat aturan fuzzy berdasarkan dari kombinasi himpunan fuzzy dari variabel inputnya. Langkah selanjutnya adalah membuat implikasi fungsi dan komposisi aturan, yang kemudian mendapatkan penegasan (defuzzyfikasi) dari daerah hasi komposisi setiap aturan yang diperoleh. Untuk memeriksa keakuratan dari penegasan yang diperoleh, penelitian ini kemudian mengaplikasikannya ke dalam bentuk sebuah studi kasus. Hasil dari perhitungan FES ini kemudian akan dibandingkan dengan hasil diagnosa dari Dokter ahli.

\section{HASIL DAN PEMBAHASAN}

Fuzzy Expert System (FES) untuk mendiagnosa penyakit dengan menggunakan metode Mamdani ini digunakan untuk menentukan persentase resiko penyakit ginjal kronis (PGK) berdasarkan data gejala dari PGK tersebut. Dari literatur berupa buku (Kapita Selekta Kedokteran Jilid 1, Cetakan Ketujuh:2005) gejala-gejala PGK adalah tekanan darah tinggi, perubahan jumlah kencing, ada darah dalam air kencing, bengkak pada bagian persendian tubuh, rasa lemah serta sulit tidur, sakit kepala, sesak nafas, mual dan muntah, kulit kasar, gangguan pengecapan, tidak nafsu makan, berat badan turun dan gatal-gatal.

Berdasarkan pendapat dokter ahli yang menangani PGK, diperoleh empat gejala yang menjadi faktor resiko untuk menentukan diagnosis PGK. Yaitu: tekanan darah tinggi, perubahan jumlah kencing, bengkak pada persendian tubuh dan mual dan muntah. 
Keempat faktor resiko inilah yang kemudian menjadi variabel fuzzy pada FES untuk diagnosis PGK. Hasil wawancara dengan dokter ahli yang menangani pasien PGK dan pasien PGK dapat dilihat pada tabel 1 dan tabel 2 berikut.

Tabel 1 Hasil Wawancara dengan dokter ahli PGK

\begin{tabular}{|c|l|c|c|}
\hline No. & \multicolumn{1}{|c|}{ Gejala } & Notasi & Konfirmasi dokter ahli \\
\hline 1. & Tekanan darah tinggi & $\mathrm{g}_{1}$ & Selalu \\
\hline 2. & Perubahan jumlah kencing & $\mathrm{g}_{2}$ & Selalu \\
\hline 3. & Bengkak pada persendian tubuh & $\mathrm{g}_{3}$ & Selalu \\
\hline 4. & Mual dan muntah & $\mathrm{g}_{4}$ & Selalu \\
\hline
\end{tabular}

Tabel 2 hasil wawancara dengan pasien PGK

\begin{tabular}{|c|l|c|c|c|c|c|c|c|c|}
\hline \multirow{2}{*}{ No. } & \multicolumn{1}{|c|}{ Gejala } & \multicolumn{6}{|c|}{ Konfirmasi pasien $(p)$ dalam satuan hari } \\
\cline { 3 - 11 } & & $p_{1}$ & $p_{2}$ & $p_{3}$ & $p_{4}$ & $p_{5}$ & $p_{6}$ & $p_{7}$ & $p_{8}$ \\
\hline 1. & Tekanan darah tinggi & 5 & 5 & 7 & 6 & 2 & 0 & 2 & 2 \\
\hline 2. & Perubahan jumlah kencing & 1 & 6 & 0 & 7 & 1 & 2 & 4 & 1 \\
\hline 3. & Bengkak pada persendian tubuh & 2 & 4 & 6 & 5 & 1 & 3 & 5 & 0 \\
\hline 4. & Mual dan muntah & 4 & 7 & 3 & 0 & 4 & 1 & 0 & 3 \\
\hline
\end{tabular}

FES yang dirancang untuk pendiagnosaan PGK ini mempunyai 4 input dan 1 output seperti terlihat pada tabel 3 , sedangkan penggambaran sistem secara keseluruhan terlihat seperti pada Gambar 1.

Tabel 3 Variabel Fuzzy Expert System (FES) beserta Himpunan input dan outputnya

\begin{tabular}{|c|c|c|c|c|}
\hline \multicolumn{2}{|l|}{ Variabel fuzzy } & \multicolumn{2}{|c|}{ Himpunan fuzzy } & \multirow{2}{*}{ Domain } \\
\hline Nama & Notasi & Nama & Notasi & \\
\hline \multirow{4}{*}{ Tekanan darah tinggi } & \multirow{4}{*}{$g_{1}$} & Tidak pernah & tp & {$[0,2]$} \\
\hline & & Jarang & jrg & {$[0,4]$} \\
\hline & & Sering & $\operatorname{srg}$ & {$[2,6]$} \\
\hline & & Selalu & sll & {$[4,7]$} \\
\hline \multirow{4}{*}{ Perubahan jumlah kencing } & \multirow{4}{*}{$g_{2}$} & Tidak pernah & tp & {$[0,2]$} \\
\hline & & Jarang & jrg & {$[0,4]$} \\
\hline & & Sering & $\operatorname{srg}$ & {$[2,6]$} \\
\hline & & Selalu & sll & {$[4,7]$} \\
\hline \multirow{4}{*}{ Bengkak pada persendian tubuh } & \multirow{4}{*}{$g_{3}$} & Tidak pernah & tp & {$[0,2]$} \\
\hline & & Jarang & jrg & {$[0,4]$} \\
\hline & & Sering & $\operatorname{srg}$ & {$[2,6]$} \\
\hline & & Selalu & sll & {$[4,7]$} \\
\hline \multirow{4}{*}{ Mual dan muntah } & \multirow{4}{*}{$g_{4}$} & Tidak pernah & tp & {$[0,2]$} \\
\hline & & Jarang & jrg & {$[0,4]$} \\
\hline & & Sering & srg & {$[2,6]$} \\
\hline & & Selalu & sll & {$[4,7]$} \\
\hline \multirow{4}{*}{ Resiko PGK } & \multirow{4}{*}{$S$} & Sangat Rendah & $\mathrm{sr}$ & {$[0,4]$} \\
\hline & & Rendah & rdh & {$[0,20]$} \\
\hline & & Sedang & sdg & {$[10,50]$} \\
\hline & & Tinggi & $\operatorname{tgg}$ & {$[30,70]$} \\
\hline
\end{tabular}




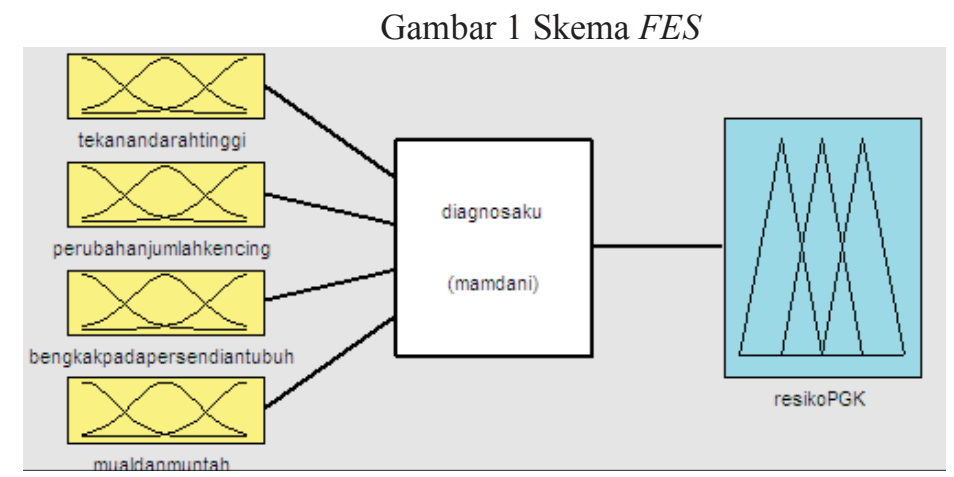

Fungsi keanggotaan yang digunakan pada tiap variabel fuzzy ditentukan secara subyektif berdasarkan pandangan para dokter ahli dan literatur yang ada dalam ilmu kedokteran. Pada umumnya derajat keanggotaan untuk setiap himpunan fuzzy mempunyai interval antara 0 sampai dengan 1 . Nilai 0 menunjukkan tidak adanya keanggotaan $(0 \%)$ sedangkan nilai 1 menunjukkan keanggotaan mutlak $(100 \%)$ di dalam himpunan fuzzy tersebut.

\subsection{Variabel tekanan darah tinggi}

Fungsi keanggotaan yang digunakan untuk merepresentasikan variabel tekanan darah tinggi pada himpunan fuzzy tidak pernah, jarang dan sering adalah fungsi keanggotaan segitiga, sedangkan untuk himpunan fuzzy selalu digunakan fungsi keanggotaan trapesium. Fungsi keanggotaan dari himpunan fuzzy tekanan darah tinggi didefinisikan sebagai berikut.

$$
\begin{aligned}
& \square_{\mathrm{tp}}\left(\mathrm{g}_{1}\right)=\left\{\begin{array}{lc}
0 ; & \square_{1} \leq 0 \square \square \square \square \quad \square_{1} \geq 2 \\
\left(2-\square_{1}\right) / 2 ; & 0<\square_{1}<2
\end{array}\right. \\
& \square_{\mathrm{jrg}}\left(\mathrm{g}_{1}\right)= \begin{cases}0 ; & \square_{1} \leq 0 \square \square \square \square \square_{1} \geq 4 \\
\square_{1} / 2 ; & 0<\square_{1} \leq 2 \\
\left(4-\square_{1}\right) / 2 ; & 2 \leq \square_{1}<4\end{cases} \\
& \square_{\mathrm{srg}}\left(\mathrm{g}_{1}\right)= \begin{cases}0 ; & \square_{1} \leq 2 \square \square \square \square \square_{1} \geq 6 \\
\left(\square_{1}-2\right) / 2 ; & 2<\square_{1} \leq 4 \\
\left(6-\square_{1}\right) / 2 ; & 4 \leq \square_{1}<6\end{cases} \\
& \square_{\mathrm{sll}}\left(\mathrm{g}_{1}\right)= \begin{cases}0 ; & \square_{1} \leq 4 \\
\left(\square_{1}-4\right) / 4 ; & 4<\square_{1} \leq 6 \\
l ; & \square_{1} \geq 7\end{cases}
\end{aligned}
$$

\subsection{Variabel perubahan jumlah kencing}

Fungsi keanggotaan yang digunakan untuk merepresentasikan variabel perubahan jumlah kencing pada himpunan fuzzy tidak pernah, jarang dan sering adalah fungsi keanggotaan segitiga, sedangkan untuk himpunan fuzzy selalu digunakan fungsi keanggotaan trapesium. Fungsi keanggotaan dari himpunan fuzzy perubahan jumlah kencing didefinisikan sebagai berikut.

$$
\begin{aligned}
& \square_{\mathrm{tp}}\left(\mathrm{g}_{2}\right)= \begin{cases}0 ; & \square_{2} \leq 0 \square \square \square \square \quad \square_{2} \geq 2 \\
\left(2-\square_{2}\right) / 2 ; & 0<\square_{2}<2\end{cases} \\
& \square_{\mathrm{jrg}}\left(\mathrm{g}_{2}\right)= \begin{cases}0 ; & \square_{2} \leq 0 \square \square \square \square \square_{2} \geq 4 \\
\square_{2} / 2 ; & 0<\square_{2} \leq 2 \\
\left(4-\square_{2}\right) / 2 ; & 2 \leq \square_{2}<4\end{cases}
\end{aligned}
$$




$$
\begin{aligned}
& \square_{\text {srg }}\left(g_{2}\right)=\left\{\begin{array}{lc}
0 ; & \square_{2} \leq 2 \square \square \square \square \square_{2} \geq 6 \\
\left(\square_{2}-2\right) / 2 ; & 2<\square_{2} \leq 4 \\
\left(6-\square_{2}\right) / 2 ; & 4 \leq \square_{2}<6
\end{array}\right. \\
& \square_{\text {sll }}\left(\mathrm{g}_{2}\right)= \begin{cases}0 ; & \square_{2} \leq 4 \\
\left(\square_{2}-4\right) / 4 ; & 4<\square_{2} \leq 6 \\
l ; & \square_{2} \geq 7\end{cases}
\end{aligned}
$$

\subsection{Variabel bengkak pada persendian tubuh}

Fungsi keanggotaan yang digunakan untuk merepresentasikan variabel bengkak pada persendian tubuh pada himpunan fuzzy tidak pernah, jarang dan sering adalah fungsi keanggotaan segitiga, sedangkan untuk himpunan fuzzy selalu digunakan fungsi keanggotaan trapesium. Fungsi keanggotaan dari himpunan fuzzy bengkak pada persendian tubuh didefinisikan sebagai berikut.

$$
\begin{aligned}
& \square_{\mathrm{tp}}\left(\mathrm{g}_{3}\right)=\left\{\begin{array}{lc}
0 ; & \square_{3} \leq 0 \square \square \square \square \quad \square_{3} \geq 2 \\
\left(2-\square_{3}\right) / 2 ; & 0<\square_{3}<2
\end{array}\right. \\
& \square_{\mathrm{jrg}}\left(\mathrm{g}_{3}\right)= \begin{cases}0 ; & \square_{3} \leq 0 \square \square \square \quad \square_{3} \geq 4 \\
\square_{3} / 2 ; & 0<\square_{3} \leq 2 \\
\left(4-\square_{3}\right) / 2 ; & 2 \leq \square_{3}<4\end{cases} \\
& \square_{\mathrm{srg}}\left(\mathrm{g}_{3}\right)= \begin{cases}0 ; & \square_{3} \leq 2 \square \square \square \square \square_{3} \geq 6 \\
\left(\square_{3}-2\right) / 2 ; & 2<\square_{3} \leq 4 \\
\left(6-\square_{3}\right) / 2 ; & 4 \leq \square_{3}<6\end{cases} \\
& \square_{\mathrm{sll}}\left(\mathrm{g}_{3}\right)= \begin{cases}0 ; & \square_{3} \leq 4 \\
\left(\square_{3}-4\right) / 4 ; & 4<\square_{3} \leq 6 \\
1 ; & \square_{3} \geq 7\end{cases}
\end{aligned}
$$

\subsection{Variabel mual dan muntah}

Fungsi keanggotaan yang digunakan untuk merepresentasikan variabel mual dan muntah pada himpunan fuzzy tidak pernah, jarang dan sering adalah fungsi keanggotaan segitiga, sedangkan untuk himpunan fuzzy selalu digunakan fungsi keanggotaan trapesium. Fungsi keanggotaan dari himpunan fuzzy mual dan muntah didefinisikan sebagai berikut.

$$
\begin{aligned}
& \square_{\mathrm{tp}}\left(\mathrm{g}_{4}\right)=\left\{\begin{array}{lc}
0 ; & \square_{4} \leq 0 \square \square \square \square \square_{4} \geq 2 \\
\left.2-\square_{4}\right) / 2 ; & 0<\square_{4}<2
\end{array}\right. \\
& \square_{\mathrm{jrg}}\left(\mathrm{g}_{4}\right)= \begin{cases}0 ; & \square_{4} \leq 0 \square \square \square \square \square_{4} \geq 4 \\
\square_{4} / 2 ; & 0<\square_{4} \leq 2 \\
\left(4-\square_{4}\right) / 2 ; & 2 \leq \square_{4}<4\end{cases} \\
& \square_{\mathrm{srg}}\left(\mathrm{g}_{4}\right)= \begin{cases}0 ; & \square_{4} \leq 2 \square \square \square \square \square_{4} \geq 6 \\
\left(\square_{4}-2\right) / 2 ; & 2<\square_{4} \leq 4 \\
\left(6-\square_{4}\right) / 2 ; & 4 \leq \square_{4}<6\end{cases} \\
& \square_{\mathrm{sll}}\left(\mathrm{g}_{4}\right)= \begin{cases}0 ; & \square_{4} \leq 4 \\
\left(\square_{4}-4\right) / 4 ; & 4<\square_{4} \leq 6 \\
1 ; & \square_{4} \geq 7\end{cases}
\end{aligned}
$$

Representasi fungsi keanggotaan pada tiap variabel input dalam penelitian ini digambarkan seperti pada gambar 2 berikut. 
Gambar 2 Representasi fungsi keanggotaan untuk variabel input

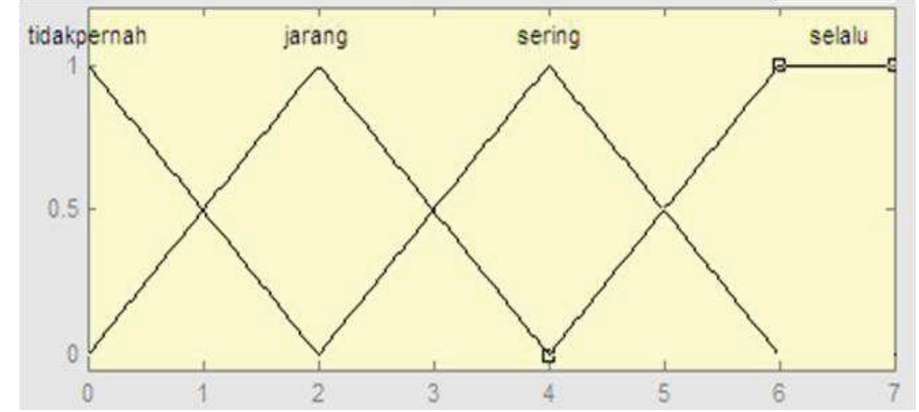

\subsection{Variabel Resiko PGK}

Fungsi keanggotaan segitiga digunakan untuk merepresentasikan variabel resiko PGK pada himpunan fuzzy Sangat Rendah, Rendah, Sedang dan Tinggi. Sedangkan untuk himpunan fuzzy Sangat Tinggi digunakan fungsi keanggotaan trapesium. Fungsi keanggotaan dari himpunan fuzzy Resiko PGK didefinisikan sebagai berikut.

$$
\begin{aligned}
& \square_{\mathrm{sr}}(S)= \begin{cases}0 ; & \square \leq 0 \square \square \square \square \\
(4-\square) / 4 ; & 0<\square<4\end{cases} \\
& \square_{\mathrm{r}}(S)= \begin{cases}0 ; & \square \leq 0 \square \square \square \square \square \geq 20 \\
\square / 10 ; & 0<\square \leq 10 \\
(20-\square) / 10 ; & 10 \leq \square<20\end{cases} \\
& \square_{\mathrm{sdg}}(S)= \begin{cases}0 ; & \square \leq 10 \square \square \square \square \square \\
\square-10 / 20 ; & 10<\square \leq 30 \\
(50-\square) / 20 ; & 30 \leq \square<50\end{cases} \\
& \square_{\mathrm{tgg}}(S)= \begin{cases}0 ; & \square \leq 30 \square \square \square \square \\
\square-30 / 20 ; & 30<\square \leq 50 \\
(70-\square) / 20 ; & 50 \leq \square<70\end{cases} \\
& \square \mathrm{st}_{\mathrm{st}}(S)= \begin{cases}0 ; \\
(\square-50) / 20 ; & 50<\square \leq 70 \\
1 ; & \square \geq 70\end{cases}
\end{aligned}
$$

Gambar 3 Representasi fungsi keanggotaan untuk variabel resiko PGK

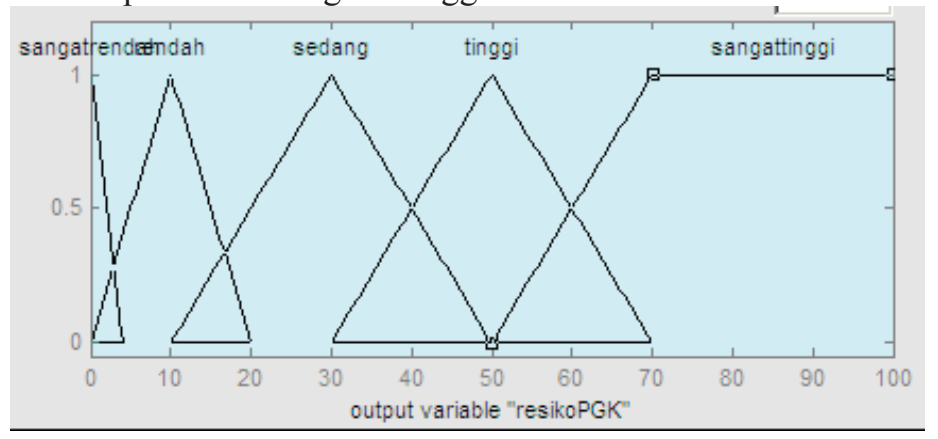

Variabel input dan output yang telah diperoleh seperti pada tabel 3 kemudian digunakan untuk membuat Fuzzy rules berdasarkan kombinasi dari himpunan Fuzzy variabel inputnya. Kemampuan untuk membuat keputusan dari suatu sistem fuzzy tertuang dalam sekumpulan rules. Secara umum, rules tersebut bersifat intuitif dan berupa 
pernyataan kualitatif yang ditulis dalam bentuk if then, sehingga mudah dimengerti. Rules pada sistem fuzzy untuk diagnosa penyakit ginjal kronis diperoleh dari intuisi, pandangan dokter ahli yang bergerak dibidang penyakit dalam khususnya yang menangani penyakit ginjal dan berdasarkan literatur.

Berdasarkan kombinasi variabel input yang ada, rules yang dapat dibentuk adalah sebanyak 256 rules. Sebagai contoh diambil Rule 1, Rule 151, dan Rule 250, yang dapat dituliskan sebagai berikut.

Rule $1 \quad$ : $\boldsymbol{I F} \mathrm{g}_{\mathbf{1}}=$ Tidak Pernah $\boldsymbol{A N D} \mathrm{g}_{2}=$ Tidak Pernah $\boldsymbol{A N D} \mathrm{g}_{3}=$ Tidak Pernah AND $\mathbf{g}_{4}=$ Tidak Pernah THEN Resiko PGK = Sangat Rendah

Rule 151

: $\boldsymbol{I F} \mathrm{g}_{1}=$ Jarang $\boldsymbol{A N D} \mathrm{g}_{2}=$ Jarang $\boldsymbol{A N D} \mathrm{g}_{3}=$ Sering $\boldsymbol{A N D} \mathrm{g}_{4}=$ Sering

THEN Resiko PGK = Sedang

Rule 250

: $\boldsymbol{I F} \mathrm{g}_{1}=$ Sering $\boldsymbol{A N D} \mathrm{g}_{2}=$ Selalu $\boldsymbol{A N D} \mathrm{g}_{3}=$ Selalu $\boldsymbol{A N D} \mathbf{g}_{4}=$ Jarang THEN Resiko PGK = Sangat Tinggi

Metode defuzzyfikasi yang digunakan pada komposisi aturan Mamdani pada FES untuk diagnosis PGK adalah metode Mean of Maximum (MOM). Pada metode ini, solusi crisp (tegas) diperoleh dengan cara mengambil nilai rata-rata domain yang memiliki nilai keanggotaan maksimum dalam Kusumadewi dan Purnomo (2004). Nilai rata-rata yang diperoleh tersebut merupakan output dari FES untuk diagnosis PGK.

\subsection{Contoh Kasus}

\subsubsection{Hasil diagnosa menggunakan FES untuk Pasien $P_{2}$}

Berdasarkan data yang terdapat ditabel 3.2, langkah pertama yang dilakukan adalah mencari derajat keanggotaan dari setiap variabel fuzzy. Dengan menggunakan persamaan (3.1), diperoleh derajat keanggotaan untuk variabel Tekanan darah tinggi untuk himpunan Fuzzy sering dan selalu adalah sebesar 0.5. Untuk variabel Perubahan jumlah kencing, digunakan persamaan (3.2) diperoleh nilai derajat keanggotaan 0 untuk himpunan Fuzzy sering dan 1 untuk himpunan Fuzzy selalu. Persamaan (3.3) untuk variabel Bengkak pada persendian tubuh memberikan nilai 0 untuk himpunan Fuzzy jarang dan selalu, sedangkan untuk himpunan Fuzzy sering memberikan nilai 1. Untuk variabel Mual dan muntah digunakan persamaan (3.4) yang memberikan nilai derajat keanggotaan untuk himpunan Fuzzy selalu sebesar 1.

Langkah kedua yakni mencari nilai $S$ untuk setiap rule dengan menggunakan fungsi Min pada aplikasi fungsi implikasinya. Fuzzy rules yang berlaku untuk Pasien $P_{2}$ adalah rules [ $\left.\mathbf{R}_{\mathbf{1 0 8}}\right],\left[\mathbf{R}_{\mathbf{1 1 2}}\right],\left[\mathbf{R}_{\mathbf{1 2 4}}\right],\left[\mathbf{R}_{\mathbf{1 2 8}}\right],\left[\mathbf{R}_{\mathbf{1 7 2}}\right],\left[\mathbf{R}_{\mathbf{1 7 6}}\right],\left[\mathbf{R}_{\mathbf{1 8 8}}\right],\left[\mathbf{R}_{\mathbf{1 9 2}}\right],\left[\mathbf{R}_{\mathbf{2 3 6}}\right],\left[\mathbf{R}_{\mathbf{2 4 0}}\right],\left[\mathbf{R}_{\mathbf{2 5 2}}\right]$ dan $\left[\mathbf{R}_{256}\right]$. Komposisi fuzzy rules dilakukan dengan menggunakan metode Max. dari inferensi metode Mamdani Max-Min didapatkan derajat keanggotaan untuk kasus ini sebagai

$$
\begin{aligned}
\operatorname{Max}\left(\square_{108}, \square_{112}, \square_{124}, \square_{128}, \square_{172}, \square_{176}, \square_{188}, \square_{192}, \square_{236}, \square_{240}, \square_{252}, \square_{256}\right) \\
\quad=\operatorname{Max}(0,0,0,0,0,0,0.5,0.5,0,0,0,0) \\
\quad=0.5
\end{aligned}
$$

Daerah hasil aplikasi komposisi aturan Max ditunjukkan oleh gambar 3.4

Gambar 3.4 Daerah hasil komposisi aturan untuk pasien $p_{2}$ 


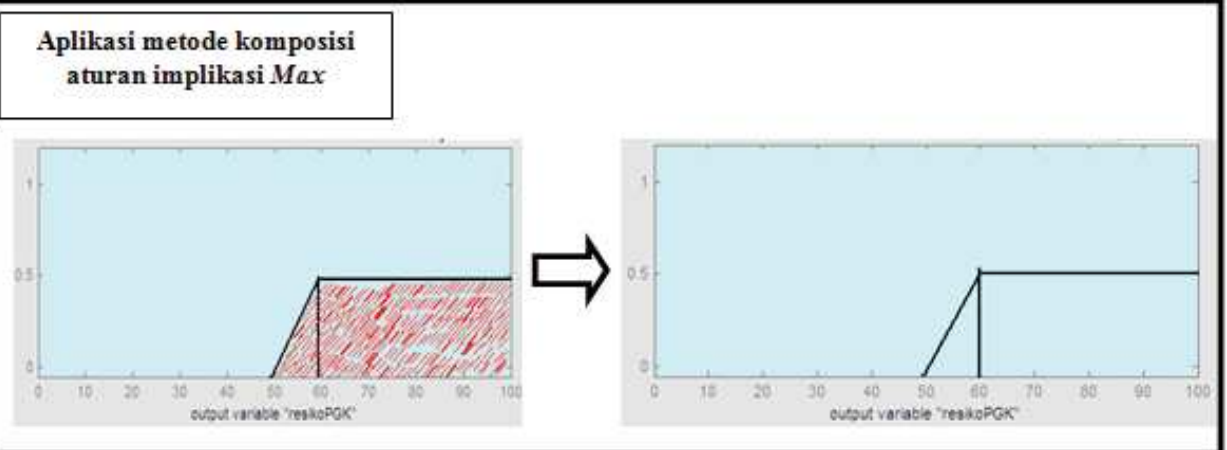

Fungsi keanggotaan untuk hasil komposisi ini adalah

$$
\square(\mathrm{s})= \begin{cases}0 ; & \square \leq 50 \\ (\square-50) / 20 ; & 50<\square \leq 60 \\ 0.5 & 60<\square \leq 100\end{cases}
$$

Metode defuzzyfikasi yang digunakan adalah metode Mean of Maximum (MOM), yaitu dengan cara mengambil nilai rata-rata maksimum daerah fuzzy (Setiadji, 2009). Maka titik pusat yang diperoleh adalah:

$$
\begin{aligned}
\mathrm{d}^{*} & =\frac{61+100}{2} \\
& =\frac{161^{2}}{2} \\
& =80.5
\end{aligned}
$$

Hal ini menunjukkan bahwa pasien $p_{2}$ memiliki persentase RPGK sebesar $80.5 \%$.

\subsubsection{Hasil diagnosa menggunakan FES untuk Pasien $P_{8}$}

Dengan menggunakan persamaan (3.1) sampai (3.4), nilai derajat keanggotaan untuk Pasien $P_{8}$ berdasarkan tabel 3.2 adalah sebagai berikut. Untuk variabel Tekanan darah tinggi diperoleh nilai 0 untuk himpunan Fuzzy tidak pernah dan sering, sedangkan untuk himpunan Fuzzy jarang diperoleh nilai sebesar 1. Untuk variabel Perubahan jumlah kencing diperoleh nilai 0.5 masing-masing untuk himpunan Fuzzy tidak pernah dan jarang. Variabel Bengkak pada persendian tubuh diperoleh nilai 1 untuk himpunan Fuzzy tidak pernah dan nilai 0 untuk himpunan Fuzzy jarang. Sedangkan untuk variabel Mual dan muntah memberikan nilai derajat keanggotan sebesar 0.5 masing-masing untuk himpunan Fuzzy jarang dan sering.

Selanjutnya, rules yang berlaku untuk Pasien $P_{8}$ adalah rules $\left[\mathbf{R}_{\mathbf{2}}\right],\left[\mathbf{R}_{\mathbf{3}}\right],\left[\mathbf{R}_{\mathbf{6}}\right]$, $\left[\mathbf{R}_{7}\right],\left[\mathbf{R}_{10}\right],\left[\mathbf{R}_{11}\right],\left[\mathbf{R}_{18}\right],\left[\mathbf{R}_{19}\right],\left[\mathbf{R}_{22}\right],\left[\mathbf{R}_{23}\right],\left[\mathbf{R}_{26}\right],\left[\mathbf{R}_{27}\right],\left[\mathbf{R}_{66}\right],\left[\mathbf{R}_{67}\right],\left[\mathbf{R}_{70}\right],\left[\mathbf{R}_{71}\right],\left[\mathbf{R}_{74}\right]$, $\left[\mathbf{R}_{\mathbf{7 5}}\right]$, [ $\left[\mathbf{R}_{\mathbf{8 2}}\right],\left[\mathbf{R}_{\mathbf{8 3}}\right],\left[\mathbf{R}_{\mathbf{8 6}}\right],\left[\mathbf{R}_{\mathbf{8 7}}\right],\left[\mathbf{R}_{\mathbf{9 0}}\right]$ dan $\left[\mathbf{R}_{\mathbf{9 1}}\right]$. Komposisi fuzzy rules dilakukan dengan menggunakan metode Max. dari inferensi Metode Mamdani Max-Min, didapatkan derajat keanggotaan untuk kasus ini sebagai

$$
\begin{aligned}
\operatorname{Max} & \left(\square_{2}, \square_{3}, \square_{6}, \square_{7}, \square_{10}, \square_{11}, \square_{18}, \square_{19}, \square_{22}, \square_{23}, \square_{26}, \square_{27}, \square_{66}, \square_{67}, \square_{70}, \square_{71}, \square_{74},\right. \\
& \left.\square_{75}, \square_{82}, \square_{83}, \square_{86}, \square_{87}, \square_{90}, \square_{91}\right) \\
& =\operatorname{Max}(0,0,0.5,0.5,0,0,0,0,0.5,0.5,0,0,0,0,0,0,0,0,0,0,0,0,0,0) \\
& =0.5
\end{aligned}
$$

Titik potong antara daerah komposisi aturan terjadi pada saat $\square_{\square \square}=\square_{\square}=0.5$, yaitu

$$
\begin{aligned}
\frac{\square}{10} & =0.5 \\
\mathrm{~s} & =(0.5)(10) \\
& =5
\end{aligned}
$$

Daerah hasil aplikasi komposisi aturan Max ditunjukkan oleh gambar 3.5 berikut.

Gambar 3.5 Daerah hasil komposisi aturan untuk Pasien $P_{8}$ 


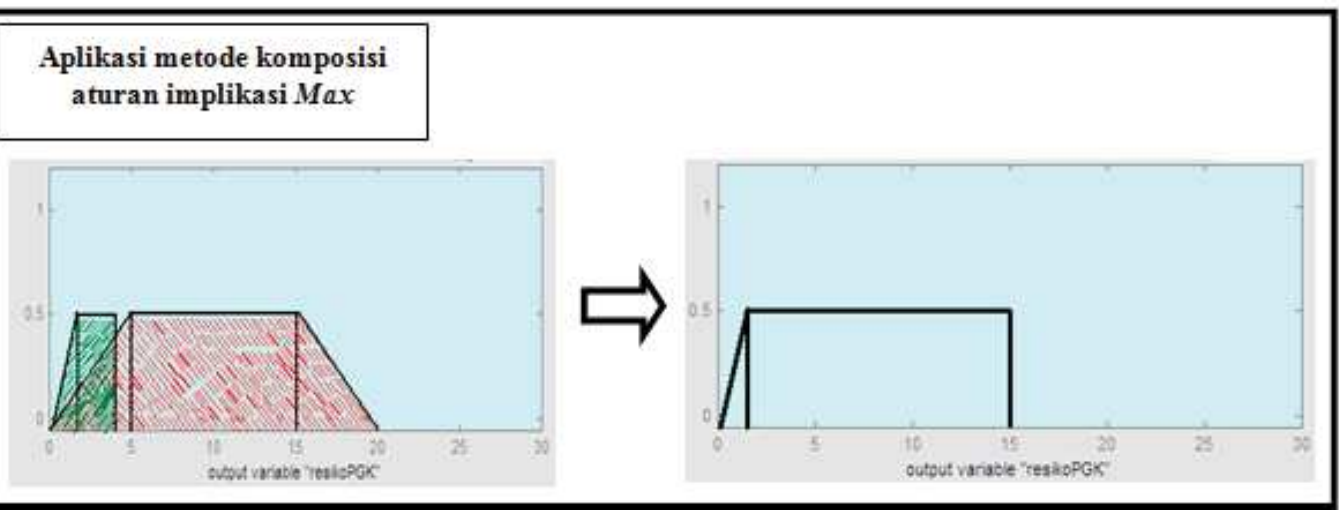

Fungsi keanggotaan untuk hasil komposisi ini adalah

$$
\square(\square)= \begin{cases}0 ; & \square \leq 0 \square \square \square \square \square \leq 20 \\ (4-\square) / 4 ; & 0<\square \leq 2 \\ 0.5 ; & 2 \leq \square \leq 15\end{cases}
$$

Metode defuzzyfikasi yang digunakan adalah metode Mean of Maximum (MOM), yaitu dengan cara mengambil nilai rata-rata maksimum daerah fuzzy (Setiadji, 2009). Maka titik pusat yang diperoleh adalah:

$$
\begin{aligned}
\mathrm{d}^{*} & =\frac{2+15}{2} \\
& =\frac{17}{2} \\
& =8.5
\end{aligned}
$$

Hal ini menunjukkan bahwa pasien $p_{8}$ memiliki persentase RPGK sebesar 8.07 \%. Dengan cara yang sama diperoleh hasil perhitungan untuk pasien $P_{1}, P_{3}$ sampai $p_{7}$.

Berdasarkan fungsi keanggotaan dari himpunan fuzzy Resiko Penyakit Ginjal Kronis (RPGK) (4.5), susunan hipotesis diagnostik yang dapat diambil untuk diagnosa seorang pasien adalah $\square_{\square \square}(\square)$ berada dalam interval [0 sampai 4], $\square_{\square}(\square)$ berada dalam interval [0 sampai 20], $\square_{\square}(\square)$ berada dalam interval [10 sampai 50], $\square_{\square}(\square)$ berada dalam interval [30 sampai 70], dan $\square \square \square(\square)$ berada dalam interval [50 sampai 100].

Dari hasil perhitungan dengan menggunakan Fuzzy Expert System (FES) menggunakan metode Mamdani, dapat dilihat bahwa pasien $p_{1}, p_{5}$ dan $p_{7}$ mempunyai nilai RPGK sebesar $10 \%$, dimana nilai ini berada pada interval RPGK rendah. Pasien $p_{2}$ mempunyai nilai RPGK sebesar $80.5 \%$, dimana nilai ini berada pada interval RPGK sangat tinggi. Pasien $p_{3}$ dan pasien $p_{4}$ mempunyai nilai RPGK sebesar $50 \%$, dimana nilai ini berada pada interval RPGK tinggi. Dan untuk pasien $p_{6}$ dan pasien $p_{8}$ mempunyai RPGK sebesar 8.5\%, dimana nilai berada pada interval RPGK rendah. Hasil perhitungan dengan Fuzzy Expert System (FES) menggunakan metode Mamdani, kemudian dibandingkan dengan hasil diagnosa dokter ahli pada tabel 4 . Tabel 4 menunjukkan bahwa penggunaan logika fuzzy dengan metode Mamdani mampu memberikan hasil diagnosa yang masih berada dalam interval diagnosa dokter yang menangani penyakit tersebut.

Tabel 6 Perbandingan Hasil Perhitungan Menggunakan FES dengan Hasil Diagnosa dokter ahli

\begin{tabular}{|l|l|l|l|}
\hline No. & Pasien & Prediksi dokter ahli & Prediksi RPGK menggunakan \\
\hline
\end{tabular}




\begin{tabular}{|c|c|c|c|}
\hline & & & FES dengan metode Mamdani (\%) \\
\hline 1 & $P_{1}$ & Maag & 10 \\
\hline 2 & $P_{2}$ & PGK & 80.5 \\
\hline 3 & $P_{3}$ & PGK & 50 \\
\hline 4 & $P_{4}$ & PGK & 50 \\
\hline 5 & $P_{5}$ & Maag & 10 \\
\hline 6 & $P_{6}$ & Hepatitis & 8.5 \\
\hline 7 & $P_{7}$ & Usus Buntu & 10 \\
\hline 8 & $P_{8}$ & Jantung & 8.5 \\
\hline
\end{tabular}

\section{KESIMPULAN}

Dari hasil dan pembahasan pada bab sebelumnya, dapat diambil kesimpulan yaitu untuk memperoleh suatu hasil diagnosa untuk seorang pasien, diperlukan empat tahapan proses yaitu, pembentukan himpunan fuzzy, aplikasi fungsi implikasi, komposisi aturan dan penegasan. Dari himpunan input fuzzy, diperoleh aturan sebanyak 256 aturan fuzzy.

Dari delapan orang pasien yang dicari nilai resiko PGK-nya diperoleh hasil untuk pasien $p_{1}, p_{5}$, dan $p_{7}$ sebesar $10 \%$, dimana berdasarkan himpunan output fuzzy nilai ini berada pada kategori resiko PGK rendah. Untuk pasien $p_{2}$ diperoleh nilai sebesar $80.5 \%$ dimana hasil ini menunjukkan bahwa pasien $p_{2}$ memiliki resiko PGK sangat tinggi, untuk pasien $p_{3}$ dan $p_{4}$ diperoleh nilai sebesar $50 \%$ yang berarti memiliki resiko PGK tinggi, dan pasien $p_{6}$ dan $p_{8}$ sebesar $8.5 \%$ yang menunjukkan nilai resiko PGK rendah. Nilai ini sesuai dengan hasil diagnosa dari para dokter ahli yang menangani pasien tersebut. Hal ini menunjukkan bahwa logika fuzzy dengan metode Mamdani dapat digunakan dalam proses pendiagnosaan penyakit.

\section{DAFTAR PUSTAKA}

Kusumadewi, Sri dan Purnomo, H, 2004, Aplikasi Logika Fuzzy Untuk Pendukung Keputusan, Graha Ilmu, Yogyakarta.

Mansjoer, A. dkk, 2005, Kapita Selekta Kedokteran Jilid 1, Cetakan Ketujuh, Media Aesculapius, Jakarta.

Saritas, I., N. Allahverdi and U. Sert, 2003, A Fuzzy Expert System Design for Diagnosis of Prostate Cancer. Proceeding on International Conference on Computer System and Technologies - CompSysTech'2003.

Setiadji, 2009, Himpunan \& Logika Samar serta Aplikasinya, Graha Ilmu, Yogyakarta. Susilo Frans, 2006, Himpunan \& Logika Kabur serta aplikasinya, Graha Ilmu, Yogyakarta. 